\begin{tabular}{|c|c|c|}
\hline $\begin{array}{l}\text { 2. To: (Receiving organization) } \\
\text { SOLID WASTE SAR ENGINEERING }\end{array}$ & $\begin{array}{l}\text { 3. From: (Originating Organization) } \\
\text { Consequence Analys is } 8 M 400\end{array}$ & $\begin{array}{r}\text { 4. Related EDT No.: } \\
\text { N/A }\end{array}$ \\
\hline $\begin{array}{l}\text { 5. Proj./Prog./Dept./Div.: } \\
\text { SA\&NE }\end{array}$ & $\begin{array}{l}\text { 6. Cog. Engr.: } \\
\text { C.H. Huang }\end{array}$ & $\begin{array}{l}\text { 7. Purchase Order No.: } \\
\text { N/A }\end{array}$ \\
\hline \multirow{2}{*}{\multicolumn{2}{|c|}{$\begin{array}{l}\text { 8. Originator Remarks: } \\
\text { The attached SD provides the toxicological dose calculations } \\
\text { for the T PTant facility. }\end{array}$}} & $\begin{array}{l}\text { 9. Equip./Component No.: } \\
\text { N/A }\end{array}$ \\
\hline & & $\begin{array}{l}\text { 10. System/Bldg./Facility: } \\
\text { T Plant Facility }\end{array}$ \\
\hline \multirow{3}{*}{\multicolumn{2}{|c|}{ 11. Receiver Remarks: }} & $\begin{array}{l}\text { 12. Major Assm. Dwg. No.: } \\
N / A\end{array}$ \\
\hline & & $\begin{array}{l}\text { 13. Permit/Permit Application No.: } \\
\text { N/A }\end{array}$ \\
\hline & & $\begin{array}{l}\text { 14. Required Response Date: } \\
N / A\end{array}$ \\
\hline
\end{tabular}

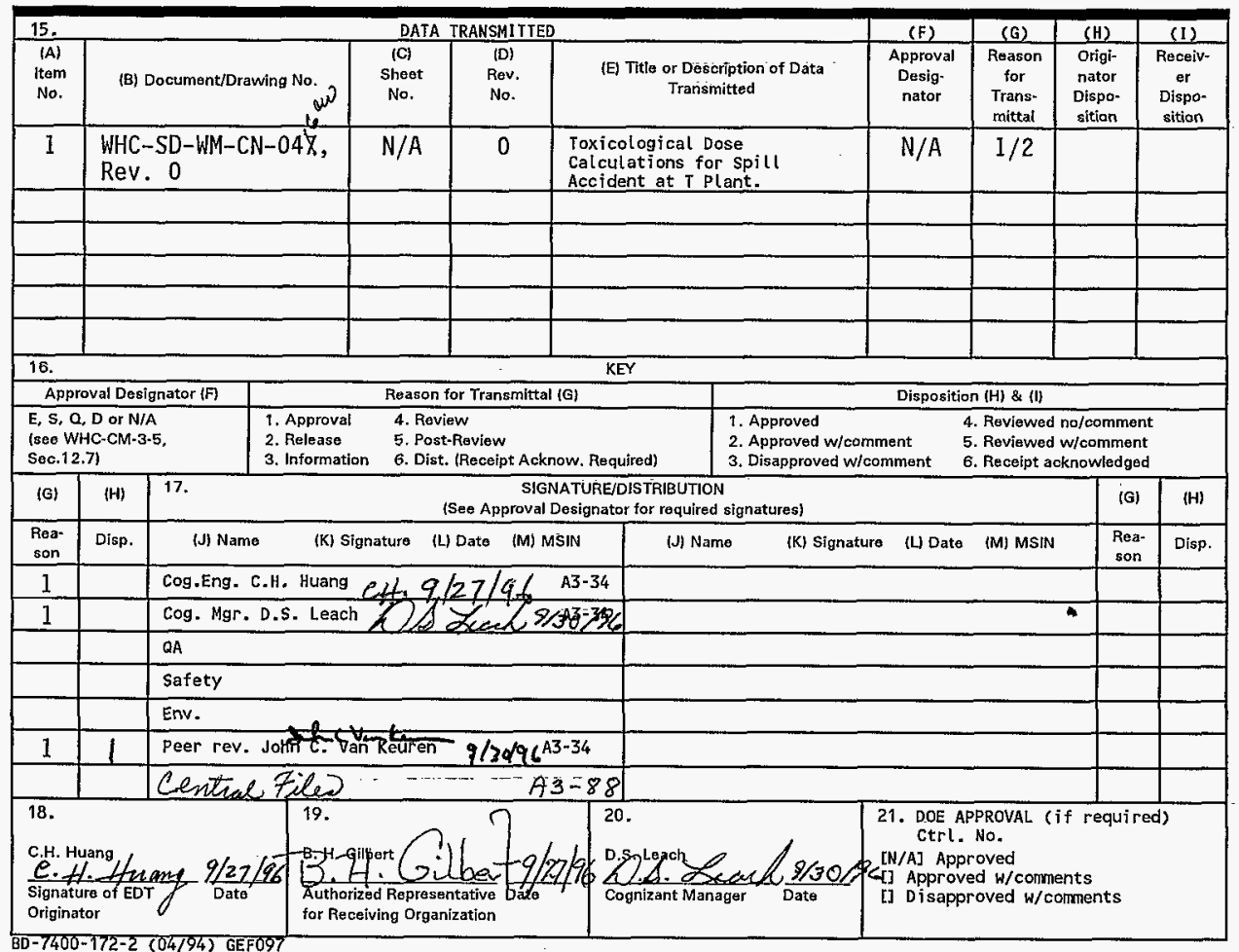


WHC-SD-WM-CN-04t, Rev. 0

\title{
TOXICOLOGICAL DOSE CALCULATIONS FOR SPILL ACCIDENT AT T PLANT
}

\author{
C. H. HUANG
}

Westinghouse Hanford, Richland, WA 99352

U.S. Department of Energy Contract DE-AC06-87RL10930

$\begin{array}{lll}\text { EDT /ECN: } & 156485 & \text { UC: } 521 \\ \text { Org Code: } & 8 M 400 & \text { Charge Code: } A B 003 \\ \text { B\&R Code: } & 39 E W 31302 & \text { Tota1 Pages: } 19\end{array}$

Key Words: Toxic Chemical Releases, Liquid Pool, Liquid Transfer, Design Basis Earthquake, Atmopsheric Dispersion, Calculation Note.

Abstract: This document provides the toxicological dose caculations related to the toxic chemical releases from spi11 accidents at $T$ Plant Facility.

TRADEMARK DISCLAIMER. Reference herein to any specific comercial product, process, or service by trade name, trademark, manufacturer, or otherwise, does not necessarily constitute or imply its endorsement, recommendation, or favoring by the United States Government or any agency thereof or its contractors or subcontractors.

Printed in the United States of America. To obtain copies of this document, contact: WHC/BCS Document Control Services, P.O. Box 1970, Mailstop H6-08, Richland WA 99352, Phone (509) 372-2420; Fax (509) 376-4989.
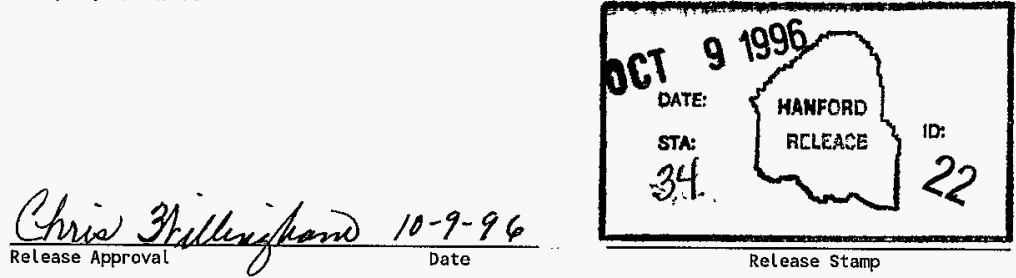

Release Stamp 
WHC-SD-WM-CN-046, Rev.0

\section{Toxicological Dose Calculations for Spill Accident at T Plant}

September 24, 1996

\section{PURPOSE}

The purpose of this document is to provide estimates for onsite and offsite consequences for two postulated accidents in the $2706 \mathrm{~T}$ Decontamination Facility located in the $200 \mathrm{~W}$ Area. These accidents are (1) a spill of decontamination waste solution at the railcar loading station and (2) liquid spill due to a beyond design basis earthquake. The spilled decontamination waste liquid results in formation of a pool and release of toxic material to atmosphere.

\section{SOURCE INVENTORY}

The following Table 1 (see Dewitt, 1996) shows the inventory of decontamination waste material contained by the decontamination waste storage tanks that is available for release for the accidents previously identified.

The hazardous wastes generated from the decontamination activities are shown in Table 1. The total volume of the spill involved is assumed to be 21,000 gallons. Table I shows the chemical concentration in liquid phase, chemical weight, weight fraction, and concentration limit (ERPG) for Sodium Hydroxide, Nitric Acid, and Sulfuric Acid. ERPG values for Potassium Permanganate and Phosphoric Acid are not available. Therefore the NIOSH Time Weighted Average value is used to establish a limiting value for Phosphoric Acid. No limiting concentrations are provided for Potassium Permanganate.

Table 1. Chemical Composition of Decontamination Liquid Waste at the 2706T Facility

\begin{tabular}{|c|c|c|c|c|c|c|c|}
\hline \multirow[t]{2}{*}{$\begin{array}{l}\text { Total volume of } \\
\text { Spill } 21,000 \mathrm{Gal} \text {. }\end{array}$} & \multirow[t]{2}{*}{$\begin{array}{l}\text { Concentration } \\
\mathrm{Kg} / \mathrm{L}\end{array}$} & \multirow{2}{*}{$\begin{array}{l}\text { Chemical } \\
\text { Weight } \\
\text { mg (Kg) }\end{array}$} & \multirow{2}{*}{$\begin{array}{l}\text { Weight } \\
\text { Fraction }\end{array}$} & \multicolumn{3}{|c|}{$\begin{array}{c}\text { ERPG } \\
\text { Concentration limits }\end{array}$} & \multirow{2}{*}{$\begin{array}{l}\text { TWA } \\
\mathrm{Ljmi} i \frac{1}{3} \mathrm{~s} \\
\mathrm{mg} / \mathrm{m}^{\mathrm{m}}\end{array}$} \\
\hline & & & & 1 & 2 & 3 & \\
\hline $\begin{array}{l}\text { Potassium } \\
\text { Permanganate }\end{array}$ & $7.57 \mathrm{E}-03$ & $\begin{array}{c}6.0 \mathrm{E}+08 \\
(602)\end{array}$ & 7.57E-03 & - & - & - & - \\
\hline Sodium Hydroxide & $2.42 \mathrm{E}-02$ & $\begin{array}{c}1.926 \mathrm{E}+09 \\
(1926) \\
\end{array}$ & $2.42 E-02$ & ${ }_{m g / m^{3}}^{2}$ & $\begin{array}{c}40 \\
\mathrm{mg} / \mathrm{m}^{3}\end{array}$ & $\underset{\mathrm{mg} / \mathrm{m}^{3}}{100}$ & - \\
\hline Nitric Acid & $1.15 \mathrm{E}-02$ & $\begin{array}{l}9.11 \mathrm{E}+08 \\
(911) \\
\end{array}$ & $1.15 \mathrm{E}-02$ & $\begin{array}{l}2 \\
\text { ppon }\end{array}$ & 25 & $\begin{array}{l}50 \\
\text { ppm }\end{array}$ & - \\
\hline Phosphoric Acid & $1.87 \mathrm{E}-02$ & $\begin{array}{c}1.488 E+09 \\
(1488)\end{array}$ & $1.87 \mathrm{E}-02$ & $=$ & - & - & $\mathrm{ST}_{\mathrm{ST}}^{1}=3$ \\
\hline Sulfuric Acid & $5.89 \mathrm{E}-03$ & $\begin{array}{c}4.68 E+08 \\
(468) \\
\end{array}$ & $5.89 E-03$ & $\stackrel{2}{\mathrm{mg} / \mathrm{m}^{3}}$ & $\mathrm{mg}_{\mathrm{m} / \mathrm{m}^{3}}^{10}$ & $\mathrm{mg}^{30} / \mathrm{m}^{3}$ & - \\
\hline Total & & (5395) & & & & & \\
\hline
\end{tabular}


WHC-SD-WM-CN-046, Rev. 0

\section{PHYSICAL AND CHEMICAL DATA}

Some available physical and chemical data for the chemical mixture are shown in Table 2. This information is needed for the calculation of the mass release rate from a liquid pool. Table 2 shows the vapor pressure of pure Tiquid and the available molecular diffusivity.

Table 2. Physical and Chemical Data.

\begin{tabular}{|l|c|c|}
\hline $\begin{array}{l}\text { Total Volume } \\
\text { of Spill } \\
21,000 \mathrm{Gal} .\end{array}$ & $\begin{array}{c}\text { Vapor Pressure } \\
\text { Pure Liquid } \\
\mathrm{mmHg} \text { at } 25^{\circ} \mathrm{C}\end{array}$ & $\begin{array}{c}\text { Diffusivity } \\
\left(\mathrm{cm}^{2} / \mathrm{s}\right)\end{array}$ \\
\hline $\begin{array}{l}\text { Potassium } \\
\text { Permanganate }\end{array}$ & - & - \\
\hline $\begin{array}{l}\text { Sodium } \\
\text { Hydroxide }\end{array}$ & $1\left(739^{\circ} \mathrm{K}\right)$ & - \\
\hline $\begin{array}{l}\text { Nitric Acid } \\
\text { Phosphoric } \\
\text { Acid }\end{array}$ & 62 & 0.123 \\
\hline Sulfuric Acid & $1.00 \mathrm{E}-06$ & - \\
\hline
\end{tabular}

\section{ACCIDENT SCENARIOS}

\section{Case 1. Spill at Loading Station.}

It is postulated that a valve positioning error or a valve failure causes 7 iquid being recirculated in the decontamination waste storage tank to be pumped into the line used to fill the railroad tank car. The transfer line is open at the railcar loading station and the entire maximum liquid content of the largest decontamination waste storage tank $\left(51 \mathrm{~m}^{3}\right)$ is discharged and falis $6.5 \mathrm{~m}$ to the loading station floor. Most of the liquid flows into the building sump except for a $36 \mathrm{~m}^{2}$ pool wjth an assumed depth of $1 \mathrm{~cm}$ which remains on the loading station floor. Although the release occurs inside the facility, no credit is taken for mitigation due to the building. The pump rate is specified to be $250 \mathrm{l} / \mathrm{min}$ so the duration of the leak is $204 \mathrm{~min}$ or $3.4 \mathrm{hr}$ assuming the discharge is not detected before the tank is empty.

The source term is the material resuspended from the resulting pool on the loading station floor. The release from the pool on the floor was estimated using the methodology and assumptions that follow. 
WHC-SD-WM-CN-046, Rev.0

\section{Case 2. Beyond Design Basis Earthquake:}

It is postulated that the beyond design basis earthquake causes piping connections to the decontamination waste tanks to fail allowing $90 \%$ of the maximum contents of both tanks (i.e., $90 \%$ of $71.5 \mathrm{~m}^{3}$ ) to drain to the catch basin where it forms a pool. A release from the pool occurs due to evaporation and entrainment for 48 hours before the pool is covered or the release otherwise stopped.

The dimensions of the catch basin at the $2706 \mathrm{~T}$ decontamination storage tank facility are:

$$
\begin{aligned}
32^{\prime} \times 23^{\prime}-4^{\prime \prime} & =746.66 \mathrm{ft}^{2-} \\
& =69.41 \mathrm{~m}^{2}
\end{aligned}
$$

\section{METHODOLOGY AND ASSUMPTIONS}

The accidental spill of toxic chemicals to the ground will form a liquid pool. The spill is a dilute solution which consists of Potassium Permanganate, Sodium Hydroxide, Nitric Acid, Phosphoric Acid, and Sulfuric Acid for the mixture. Due to the restriction of the physical and chemical data and the complexity of the problem, it is necessary to use various approaches to calculate the mass release rate for various chemicals. The three approaches considered are as follows:

1). Raoult's Law.

In establishing the dynamic equilibrium for an ideal liquid, the vapor pressure at the air-liquid interface may be expressed by the Raoult's law as:

$$
\mathrm{p}_{\mathrm{v}}=\mathrm{x}_{\mathrm{a}} \mathrm{P}_{\mathrm{l}}
$$

where $p_{v}$ is the equilibrium vapor pressure of a species in vapor phase over the solution, i.e., above the air-liquid interface; $x_{a}$ is the mole fraction of species $A$ in the liquid phase; and $P_{l}$ is the pure vapor pressure of a species measured at the equilibrium temperature of the solution.

\section{2). Henry's Law.}

A common form of nonideal behavior over a limited range of concentration, is given by Henry's law. The Henry's Law can be used to calculate the liquid vapor pressure at the air-liquid interface for the dilute solutions. The Henry's Law may be written as

$$
\mathrm{p}_{\mathrm{v}}=\mathrm{H} \mathrm{x}_{\mathrm{a}}
$$


WHC-SD-WM-CN-046, Rev.0

Where $p_{y}$ is the vapor pressure of species $A, H$ the Henry's constant, an empirical constant which depends on temperature and pressure, and $x_{a}$ the mole fraction of species $A$.

The mole fraction of species $A$ in liquid phase can be expressed as

$$
\begin{aligned}
x_{a} & =c_{a} / c \\
& =M \rho_{a} /\left(M_{d} \rho\right)
\end{aligned}
$$

Where $c_{a}$ is the molar density of species $A$, and $c$ is the molar density of the mixture. $M$ and $M_{a}$ are the molecular weight of the mixture and the spices $A$, respectively. $\rho$ and $\rho_{a}$ are the density of the mixture and the species $A$ in solute, respectively.

The Henry's Law constant, H, may be defined as the ratio of the vapor pressure of species $A$ in air to its concentration (or mole fraction) in liquid at equilibrium. Since the mole fraction of a species is related to the weight fraction of a species, w, for convenience, the Henry's Law, Eq. (2) may also be expressed as:

$$
P_{v}=H^{\prime} w
$$

Thus, the Henry' Law constant, H', for Nitric Acjd can be derived from the available experimental data which yield more realistic results.

\section{3). Aerosol Release Rate.}

Airborne release fractions for a variety of releases are provided by Mishima (1994; DOE-HDBK-3010-94). A method for estimating the airborne release rate from a pond is given in DOE-HDBK-3010-94 (1994). This method will be utilized to estimate the airborne release from a liquid poot.

\section{An Evaporation Model}

An evaporation model for estimating the mass release rate has been derived by Huang (1996b;1996c). For a circular pool area of radius $r$, the rate of evaporation from a liquid pool into the atmosphere may be written as:

$$
E_{T}(r)=\operatorname{c~Sc}^{-2 / 3} X_{s} u^{0.78} r^{3.9}
$$

Where $c=1.64 \times 10^{-2}$ is a constant; $u$ the horizontal mean wind speed; Sc $(v / D)$ the Schmidt number, where $v$ is the air viscosity and $D$ the diffusivity; and $X_{s}$ the saturation vapor concentration at the air-liquid interface. The 
WHC-SD-WM-CN-046, Rev.0

vapor concentration can be calculated through the equation of state when the vapor pressure at the air-7iquid surface is known.

\section{CALCULATIONS AND RESULTS}

\section{Case 1. Spill at Loading Station.}

The spill volume for case. 1 is 21,000 gallons and the pool area is $36 \mathrm{~m}^{2}$.

For a circular pool, the radius, $r$, can be calculated as:

$$
A=\pi \times r^{2}
$$

where $A$ is the area of the circuiar pool. Thus, the radius, $r$, is:

$$
\begin{aligned}
r & =(A / \pi)^{0.5} \\
& =(36 / 3.14159)^{0.5} \\
r & =3.385 \mathrm{~m}
\end{aligned}
$$

\section{Nitric Acid}

According to the data (Perry and Green, 1984), the vapor pressure for Nitric Acid at $25{ }^{\circ} \mathrm{C}$ for a weight percentage of $40 \%$ is $0.12 \mathrm{mmHg}$. Thus, the Henry's constant in Eq. (4), $\mathrm{H}^{\prime}$, can be estimated as:

$$
H^{\prime}=0.12 \mathrm{mmHg} / 0.4=0.3 \mathrm{mmHg}
$$

Therefore, for Nitric Acid with the weight fraction of $1.15 \times 10^{-2}$ (see Table $1)$, the vapor pressure at the air-liquid interface is calculated from Eq. (4) as:

$$
\begin{aligned}
P_{v} & =0.3 \times 1.15 \times 10^{-2} \mathrm{mmHg} . \\
& =3.45 \times 10^{-3} \mathrm{mmHg} .
\end{aligned}
$$

For a wind speed of $5 \mathrm{~m} / \mathrm{s}$ (only used to generate the rate of evaporation) and with the known vapor pressure at the air-liquid interface, the rate of evaporation for Nitric Acid calculated by using Eq. (5) is $5.98 \times 10^{-3} \mathrm{~g} / \mathrm{s}$ (see Appendix A).

The Raoult's law is used to calculate the vapor pressure for Phosphoric Acid and Sulfuric Acid. 
WHC-SD-WM-CN-046, Rev.0

Phosphoric Acid ( $M=98.00 \mathrm{gram} / \mathrm{mole}$ ).

The mole fraction of Phosphoric Acid can be calculated as:

$$
\begin{aligned}
x_{\mathrm{a}} & =\mathrm{Mo}_{\mathrm{a}} /\left(\mathrm{M}_{\mathrm{a}} \rho\right) \\
& =(18 / 98)\left(1.87 \times 10^{-2}\right) \\
& =3.43 \times 10^{-3}
\end{aligned}
$$

Therefore, the vapor pressure for Phosphoric Acid at the air-water interface is:

$$
\begin{aligned}
p_{v} & =x_{a} P_{l} \\
& =3.43 \times 10^{-3} \times 5.82 \times 10^{-2} \mathrm{mmHg} \\
p_{v} & =2.00 \times 10^{-4} \mathrm{mmHg}
\end{aligned}
$$

Sulfuric Acid ( $M=98.08 \mathrm{gram} / \mathrm{mole}$ ).

The mole fraction of Sulfuric Acjd can be calculated as

$$
\begin{aligned}
x_{a} & =M \rho_{a} /\left(M_{d} \rho\right) \\
& =(18 / 98.08)\left(5.89 \times 10^{-2}\right) \\
& =1.08 \times 10^{-2}
\end{aligned}
$$

Therefore, the vapor pressure at the air-water interface is:

$$
\begin{aligned}
p_{v} & =x_{a} P_{l} \\
& =1.08 \times 10^{-2} \times 1.00 \times 10^{-6} \mathrm{mmHg} \\
p_{v} & =1.08 \times 10^{-8} \mathrm{mmHg}
\end{aligned}
$$

The vapor pressures over the liquid solution for the chemicals of Nitric Acid, Phosphoric Acid, and Sulfuric Acid were calculated and are summarized in Table 3 . And the calculated evaporation rate for various 1 iquids is given in Appendix A. 
WHC-SD-WM-CN-046, Rev. 0

Table 3. Vapor Pressure for Various Chemicals at the Air-Liquid Interface.

\begin{tabular}{||l|c|c|c|c||}
\hline $\begin{array}{l}\text { Total Volume } \\
\text { of Spil1 } \\
21,000 \mathrm{Gal}\end{array}$ & $\begin{array}{c}\text { Vapor Pressure } \\
\text { Pure Liquid } \\
\mathrm{mmHg} \text { at } 25^{\circ} \mathrm{C}\end{array}$ & $\begin{array}{c}\text { Mole } \\
\text { Fraction }\end{array}$ & $\begin{array}{c}\text { Weight } \\
\text { (Mass) } \\
\text { Fraction }\end{array}$ & $\begin{array}{c}\text { Vapor } \\
\text { Pressure at } \\
\text { the interface } \\
\text { mmHg }\end{array}$ \\
\hline $\begin{array}{l}\text { Potassium } \\
\text { Permanganate }\end{array}$ & - & - & $7.57 \mathrm{E}-03$ & - \\
\hline $\begin{array}{l}\text { Sodium } \\
\text { Hydroxide }\end{array}$ & - & - & $2.42 \mathrm{E}-02$ & - \\
\hline $\begin{array}{l}\text { Nitric Acid } \\
\text { Phosphoric }\end{array}$ & 62 & $3.29 \mathrm{E}-03$ & $1.15 \mathrm{E}-02$ & \\
\hline Acid & $5.80 \mathrm{E}-02$ & $3.43 \mathrm{E}-03$ & $1.87 \mathrm{E}-02$ & $2.00 \mathrm{E}-04$ \\
\hline Sulfuric Acid & $1.00 \mathrm{E}-06$ & $1.08 \mathrm{E}-02$ & $5.89 \mathrm{E}-03$ & $1.08 \mathrm{E}-08$ \\
\hline
\end{tabular}

Potassium Permanganate and Sodium Hydroxide.

Airborne release fractions for a variety of releases are provided by Mishima (1994; DOE-HDBK-301-94). The method for estimating the airborne release rate will be utilized to estimate the airborne release for Potassium Permanganate and Sodium Hydroxide from a liquid pool. The mass release rate can be estimated from the Fig.3-8 (DOE-HDBK-3010-94). In the figure the mass release rate is expressed as a function of downwind fetch and wind speed. For the wind speed, $u$, of $5 \mathrm{~m} / \mathrm{s}$, the mass release rate can be approximated as

$$
F m=B X \text { for } u=5 \mathrm{~m} / \mathrm{s}
$$

Where $\mathrm{Fm}$ is the mass release rate $\left(\mathrm{kg} / \mathrm{m}^{2} \mathrm{~s}\right), \mathrm{B}$ is a constant, and $X(\mathrm{~m})$ is the fetch, the distance from the leading edge in the downwind direction. The estimated value of $B$ is $1.25 \times 10^{-12}\left(\mathrm{~kg} / \mathrm{m}^{3} \mathrm{~s}\right)$ which was obtained from $\mathrm{Fig.3}-8$ (DOE-HDBK-3010-94).

Thus, for a circular area of $36 \mathrm{~m}^{2}$ (equivalent to a square area with a fetch of $6 \mathrm{~m})$, the mass release rate is:

$M R=F m \times A=B \times A$ 
WHC-SD-WM-CN-046, Rev.0

$=1.25 \times 10^{-12}\left(\mathrm{~kg} / \mathrm{m}^{3} \mathrm{~s}\right) \times 6 \mathrm{~m} \times 36 \mathrm{~m}^{2}$

$=2.7 \times 10^{-10} \mathrm{~kg} / \mathrm{s}$

$=2.7 \times 10^{-10} \mathrm{~L} / \mathrm{s}$

Thus, the mass release rate for Potassium Permanganate with the concentration of $7.57 \times 10^{-3} \mathrm{Kg} / \mathrm{L}$ is:

$$
\begin{aligned}
\text { MR } & =7.57 \times 10^{-3} \mathrm{Kg} / \mathrm{L} \times 2.7 \times 10^{-10} \mathrm{~L} / \mathrm{s} \\
& =2.04 \times 10^{-12} \mathrm{Kg} / \mathrm{s} \\
& =2.04 \times 10^{-6} \mathrm{mg} / \mathrm{s}
\end{aligned}
$$

Thus, the mass release rate for Sodium Hydroxide with the concentration of $2.42 \times 10^{-2} \mathrm{Kg} / \mathrm{L}$ is:

$$
\begin{aligned}
\text { MR } & =2.42 \times 10^{-2} \mathrm{Kg} / \mathrm{L} \times 2.7 \times 10^{-10} \mathrm{~L} / \mathrm{s} \\
& =6.53 \times 10^{-12} \mathrm{Kg} / \mathrm{s} \\
& =6.53 \times 10^{-6} \mathrm{mg} / \mathrm{s}
\end{aligned}
$$

The calculated mass release rate for Potassium Permanganate and Sodium Hydroxide are given in Table 4 (an alternative method for the estimation of the mass release rate has been proposed by Huang (1995); the method takes into account the characteristics of the atmospheric flow).

The mass release rate for Nitric Acid, Phosphoric Acid, and Sulfuric Acjd in the solution calculated from Eq.(5) are also shown in Table 4. 
WHC-SD-WM-CN-046, Rev.0

Table 4. The Calculated Mass Release Rate.

\begin{tabular}{||l|c|c|c|c||}
\hline $\begin{array}{l}\text { Total Volume } \\
\text { of Spi11 } \\
21,000 \mathrm{Ga} .\end{array}$ & $\begin{array}{r}\text { Vapor Pressure } \\
\mathrm{mmHg} \text { at } 25^{\circ} \mathrm{C}\end{array}$ & $\begin{array}{c}\text { Diffusivity } \\
\mathrm{cm}^{2} / \mathrm{s}\end{array}$ & $\begin{array}{c}\text { Weight } \\
\text { Fraction }\end{array}$ & $\begin{array}{c}\text { Evaporation } \\
\text { Rate } \\
\text { (mg/s) }\end{array}$ \\
\hline $\begin{array}{l}\text { Potassium } \\
\text { Permanganate }\end{array}$ & - & - & $7.57 \mathrm{E}-03$ & $2.04 \mathrm{E}-6$ \\
\hline $\begin{array}{l}\text { Sodjum } \\
\text { Hydroxide }\end{array}$ & - & - & $2.42 \mathrm{E}-02$ & $6.53 \mathrm{E}-6$ \\
\hline $\begin{array}{l}\text { Nitric Acid } \\
\text { Phosphoric } \\
\text { Acid }\end{array}$ & $3.45 \mathrm{E}-3$ & 0.123 & $1.15 \mathrm{E}-02$ & 5.98 \\
\hline \\
Sulfuric Acid
\end{tabular}

The calculated $X / Q$ values for various onsite and offsite receptor locations for T Plant are shown in Table 5 (Huang, 1996a).

Table 5: $\quad 99.5$ Percentile Dispersion Factors $(X / Q)$ at Various Onsite and offsite Receptor Locations (Acute Ground Level Releases).

\begin{tabular}{|c|c|c|c|}
\hline Case & Receptor $\cdots$ & $\begin{array}{l}\text { No Plume Meannder } \\
x / Q\left(\mathrm{~s} / \mathrm{m}^{3}\right)\end{array}$ & $\begin{array}{l}P(\text { tume Méander } \\
\times / Q\left(\mathrm{~s} / \mathrm{m}^{3}\right)\end{array}$ \\
\hline 1 & $100 \mathrm{~m}$ & $3.41 \mathrm{E}-02(\mathrm{E})$ & $1.13 \mathrm{E}-02$ (ESE) \\
\hline 2 & $500 m($ SSE $) *$ & $1.00 \mathrm{E}-03$ & $3.94 E-04$ \\
\hline 3 & $1000 \mathrm{~m}$ & $6.88 \mathrm{E}-04$ (E) & $2.46 E-04$ (ESE) \\
\hline 4 & $\begin{array}{c}\text { site Boundary } \\
(13.09 \mathrm{~km})\end{array}$ & $1.52 E-05(\mathrm{~W})$ & $1.25 \mathrm{E}-05(\mathrm{~W})$ \\
\hline 5 & $\begin{array}{l}\text { Near River } \\
(8.98 \mathrm{~km})\end{array}$ & $2.74 \mathrm{E}-05$ (N) & $2.07 \mathrm{E}-05(\mathrm{~N})$ \\
\hline 6 & $\begin{array}{c}240 \mathrm{Highway} \\
(5.89 \mathrm{~km})\end{array}$ & $4.26 E-05(W)$ & $2.92 \mathrm{E}-05(\mathrm{~W})$ \\
\hline
\end{tabular}


WHC-SD-WM-CN-046, Rev.0

From the mass release rate (see Table 4) and the value of $X / Q$ (see Table 5), we can calculate the chemical concentrations at various receptor locations. The calculated chemical concentrations and ERPG concentration limits for onsite and offsite receptors are shown in TabTe 6 . The ERPG concentration limits are obtained from Table 1 and based on the frequency for spil1 according to WHC-CM-5-34 (1996). The frequency for spill is $3 \times 10^{-2} / \mathrm{yr}$ for the anticipated event. Thus, ERPG 1 and PEL-TWA values are used as criteria to make comparisons with the calculated concentration values for the onsite and offsite receptors, respectively.

Table 6. Concentration Limits and the Calculated Onsite and Offsite Chemical Concentrations.

\begin{tabular}{|c|c|c|c|c|c|c|}
\hline \multirow{2}{*}{$\begin{array}{l}\text { Total Volume of } \\
\text { spill } 21,000 \text { Gal. }\end{array}$} & \multicolumn{2}{|c|}{$\begin{array}{l}\text { ERPG Concentsation } \\
\left.\text { limits ( } \mathrm{mg} / \mathrm{m}^{3}\right)\end{array}$} & \multicolumn{4}{|c|}{ Concentration $\left(\mathrm{mg} / \mathrm{m}^{3}\right)$} \\
\hline & Onsite & offsite & $100 \mathrm{~m}$ & $\begin{array}{l}\text { Facility } \\
500 \mathrm{~m} \\
\text { (SSE) }\end{array}$ & $\begin{array}{l}\text { Site } \\
\text { Boundary }\end{array}$ & Near River \\
\hline $\begin{array}{l}\text { Potassium } \\
\text { Permanganate }\end{array}$ & - & $=$ & $6.96 \mathrm{E}-08$ & $2.04 E-09$ & $3.10 E-11$ & $5.59 E-11$ \\
\hline Sodium Hydroxide & 2 & 2 & $2.23 E-07$ & $6.53 \mathrm{E}-09$ & $9.92 E-11$ & $1.79 E-10$ \\
\hline Nitric Acid & (2. pppm) & (2 $\left.\begin{array}{l}5 \\
\mathrm{ppm}\end{array}\right)$ & $2.04 E-01$ & $5.98 \mathrm{E}-03$ & $9.09 E-05$ & $1.64 \mathrm{E}-04$ \\
\hline Phosphoric Acid & $\begin{array}{c}1 \\
\text { (ST }=3)\end{array}$ & $\begin{array}{c}1 \\
(S T=3)\end{array}$ & $1.24 \mathrm{E}-02$ & $3.62 E-04$ & $5.50 \mathrm{E}-06$ & $9.92 E-08$ \\
\hline Sulfuric Acid & 2 & 1 & $7.43 \mathrm{E}-07$ & $2.18 \mathrm{E}-08$ & $3.31 \mathrm{E}-10$ & $5.97 \mathrm{E}-10$ \\
\hline
\end{tabular}

Table 6 shows that the calculated concentrations for various chemicals at various receptor locations are within the criteria of the concentration limits.

\section{Case 2. Beyond Design Basis Earthquake.}

The area ratio of case 2 to case 1 is:

$$
69.41 \mathrm{~m}^{2} / 36 \mathrm{~m}^{2}=1.93
$$

Applying this scaling factor of 1.93 to Table 6 , we obtain the chemical concentrations at the receptor locations for Design Basis Earthquake (case 2). The results are shown in Table 7 . Table 7 shows the calculated concentrations for various chemicals at receptor locations. No limits are established for BDBE events with frequency of occurrence less than $1.0 \times 10^{-6} / \mathrm{yr}$. However, by 
WHC-SD-WM-CN-046, Rev.0

comparing the concentration vaTues in TabTe 7 with ERPG and TWA values in Table 1, it is evident that none of these concentration values are exceeded.

Table 7. Calculated Chemical Concentrations for Beyond Design Basis Earthquake.

\begin{tabular}{|c|c|c|c|c|}
\hline \multirow{2}{*}{$\begin{array}{l}\text { Total Volume of } \\
\text { Spill 21,000 Gal. }\end{array}$} & \multicolumn{4}{|c|}{ Concentrations $\left(\mathrm{mg} / \mathrm{m}^{3}\right)$} \\
\hline & Onsite & $\begin{array}{c}\text { Facility } \\
500 \text { m (SSE) }\end{array}$ & $\begin{array}{l}\text { Site } \\
\text { Boundary }\end{array}$ & Near River \\
\hline $\begin{array}{l}\text { Potassium } \\
\text { Permanganate }\end{array}$ & $1.34 E-07$ & 3.94 E-09 & $5.98 \mathrm{E}-11$ & $1.08 E-10$ \\
\hline Sodium Hydroxide & $4.30 \mathrm{E}-07$ & $1.26 \mathrm{E}-08$ & $1.91 \mathrm{E}-10$ & $3.45 E-10$ \\
\hline Nitric Acid & $3.94 E-01$ & $1.15 \mathrm{E}-02$ & $1.75 \mathrm{E}-04$ & $3.17 E-04$ \\
\hline Phosphoric Acid & 2.39E-02 & $6.99 \mathrm{E}-04$ & $1.06 \mathrm{E}-05$ & $1.91 \mathrm{E}-05$ \\
\hline Sulfuric Acid & $1.43 \mathrm{E}-06$ & 4.21E-08 & $6.39 \mathrm{E}-10$ & $1.15 \mathrm{E}-09$ \\
\hline
\end{tabular}


WHC-SD-WM-CN-046, Rev.0

\section{REFERENCES}

Dewitt, K. E., 1996., Safety Assessment for Project W-259 T PTant Secondary Containment and Leak Detection Upgrades, WHC-SD-W259-SA-001, Rev. 0. Westinghouse Hanford Company, Richland, Washington.

Huang, C. H., 1995: Estimate of Aerosol Release from A Wind Action Over A PooT Surface for Safety Analysis. The Department of Energy EFCOG 1995 Safety Analys is Workshop, 19-23, Augusta, Georgia.

Huang, C. H., 1996a: Atmospheric Dispersion Factors for T Plant Complex. WHCSD-WM-CM-026, Rev. 0, Westinghouse Hanford Company, Richland, Washington.

Huang, C. H., 1996b: Pasquill's Influence: On the Evaporation from Various Liquids into the Atmosphere. In Pasquill Special Memorial Sessions, Ninth Joint Conference on the Applications of Air Pollution Meteorology with the Air and Waste Management Association, American Meteorological Society. AtIanta, Georgia, January 28 - February 2, 1996.

Huang, C. H., 1996c: A Method of Estimating Toxic Chemical Release from A Liquid Pool. The Department of Energy EFCOG 1996 Safety Analys is Workshop, 5-7 June 1996, Knoxville, Tennessee.

Perry, R. H., and D. Green., 1984: Chemica] Engineer's Handbook, McGrawHi11, Inc., New York, New York.

DOE, 1994: DOE Handbook, Ajrborne Release Fractions/Rates and Respirable Fractions for Nonreactor Nuclear Facilities. DOE-HDBK-3010-94, 1994.

WHC, 1996., Solid Waste Disposal Operations Administration, WHC-CM-5-34, Section 1.15. Westinghouse Hanford Company, Richland, Washington. 
WHC-SD-WM-CN-046, Rev.0

APPENDIX A

CALCULATIONS OF EVAPORATION RATE 
WHC-SD-WM-CN-046, Rev.0

VAPOR CONCENTRATION: XS

$$
\begin{aligned}
& p:=3.45 \cdot 10^{-3} \quad \mathrm{~mm} \mathrm{Eq} \text { nitric acid: ANO3 } \\
& \text { DV }:=0 \cdot 1.01325 \cdot \frac{10^{5}}{760} \\
& \mathrm{pv}=0.4 \sigma \\
& \mathrm{pa}=\mathrm{N} / \mathrm{m} \cdot \mathrm{m} \\
& \text { InT }:=0.06302 \\
& \mathrm{~kg} / \mathrm{mol} \\
& \text { t?: }:=298 \\
& r:=8.314
\end{aligned}
$$

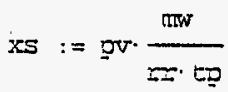

$$
\begin{aligned}
& x s=1.17 \cdot 10^{-5} \quad \mathrm{~kg} / \mathrm{m} \times 3 \\
& 11:=5 \text {. } \\
& \mathfrak{m} / \mathrm{s} \\
& r:=3.385 \\
& \text { II } \\
& \text { mII }:=0.15 \\
& \mathrm{~cm} / \mathrm{s} * \dot{S} \\
& \text { difi }:=0.123 \\
& \text { Sc : : } \frac{\text { mu }}{\text { dif }} \\
& \text { sc }=1.22 \\
& \text { cs }:=1.64 \cdot 10^{-2} \\
& \text { et }:=\mathrm{cs} \cdot \mathrm{sc}^{-0.57} \cdot \mathrm{us}^{0.78} \cdot \mathrm{u}^{1.9} \\
& \text { et }=5.979 \cdot 10^{-5} \mathrm{~kg} / \mathrm{s}
\end{aligned}
$$


WHC-SD-WM-CN-046, Rev.0

Eile : pools.mcd---dat: 9/23/96

VAPOR CONCENTRATION: XS

$$
\begin{aligned}
& p:=1.08 \cdot 10^{-8} \text { nan } \mathrm{Hg} \quad \text { sulfuric acid - } \mathrm{H} 2 \mathrm{SO} 4 \\
& \mathrm{pV}:=\mathrm{p} \cdot 1.01325 \cdot \frac{10^{5}}{760} \\
& \mathrm{pv}=1.44 \cdot 10^{-6} \quad \mathrm{pa}=\mathrm{N} / \mathrm{m} \cdot \mathrm{m} \\
& \text { mW }:=0.09808 \quad \mathrm{~kg} / \mathrm{mol} \\
& \mathrm{tP}:=298 \\
& \text { II }:=8.314 \\
& \mathrm{xs}:=\mathrm{pv} \cdot \frac{\mathrm{mw}}{\mathrm{rr} \cdot \mathrm{tp}} \\
& \mathrm{xs}=5.7 .10^{-11} \mathrm{~kg} / \mathrm{m} * 3
\end{aligned}
$$

EVAPORATION RATE : ET

$$
\begin{array}{ll}
\text { u }:=5 . & \mathrm{m} / \mathrm{s} \\
r:=3.385 & \mathrm{~m} \\
\mathrm{mu}:=0.15 & \mathrm{~cm} / \mathrm{s}^{* \mathrm{~s}} \\
\text { dif }:=0.08 & \\
\text { sc }:=\frac{\mathrm{mu}}{\mathrm{dif}} \\
\text { sc }=1.875 \\
\text { cs }:=1.64 \cdot 10^{-2} \\
\text { et }:=\mathrm{cs} \cdot \mathrm{sc}-0.67 \cdot \mathrm{xs} \cdot \mathrm{u}^{0.78} \cdot \mathrm{r}^{1.9} \\
\text { et }=2.184 \cdot 10^{-11} \mathrm{~kg} / \mathrm{s}
\end{array}
$$


file : pools.mcd---dat: 6/13/96

VAEOR CONCUNTRATION: XS

$$
\begin{aligned}
& \text { phosphoric acid - p } \\
& p:=2.0 \cdot 10 \\
& \text { เมxn ㅌg } \\
& \mathrm{pV}:=p \cdot 1.01325 \cdot \frac{10^{5}}{760} \\
& \mathrm{pv}=0.027 \\
& \mathrm{pa}=\mathrm{N} / \mathrm{m} \cdot \mathrm{m} \\
& \mathrm{nTw}:=0.098 \\
& \mathrm{~kg} / \mathrm{mol} \\
& \text { to: }=298 \\
& 5:=8.314 \\
& x s:=\operatorname{gr} \cdot \frac{\pi w}{I x \cdot t \underline{T}} \\
& x s=1.055 \cdot 10^{-5} \\
& \text { at } 25 \mathrm{C}
\end{aligned}
$$


WHC-SD-WM-CN-046, Rev.0

CHECKLIST FOR PEER REVIEN

Document Reviewed: C. H. Huang, "TOXICOLOGICAL DOSE CALCULATIONS FOR SPILL ACCIDENT AT T. PLANT," September 24, 1996.

Scope of Review: Entire Document

Yes No NA

[X] [ ] [ ]* Previous reviews complete and cover analysis, up to scope of this review, with no gaps.

[X] [ ] [ ] Probiem completely defined.

Accident scenarios developed in a clear and logical manner. Necessary assumptions explicitly stated and supported: Computer codes and data files documented. Data used in calculations explicitly stated in document. Data checked for consistency with original source information as applicabie.

[]$\cdot[] \ltimes]$ Mathematical derivations checked including dimensional consistency of results.

[X] [ ] [ ] Models appropriate and used within range of validity or use outside range of established validity justified.

[X] [ ] [ ] Hand calcuiations checked for errors. Spreadsheet results should be treated exactiy the same as hand calculations.

[ ] [ ] [X] Software input correct and consistent with document reviewed. Software output consistent with input and with results reported in document reviewed.

[X] [ ] [ ] Limits/criteria/guidelines applied to analysis results are appropriate and referenced. Limits/criteria/guidelines checked against references.

[ ] [ ] $\times]$ Safety margins consistent with good engineering practices. Conclusions consistent with analytical results and applicable 1 imits.

[x] [ ] [ ] Results and conclusions address all points required in the problem statement.

[ ] [ ] $]$ Format consistent with appropriate NRC Regulatory Guide or other standards

[]$[x *$ Review calculations, comments, and/or notes are attached.

D] [ ] [ ]. Document approved.

$\frac{\text { J.c } V_{a} \alpha k \in u R \varepsilon_{N} \text { \& } V_{m} k}{\text { Reviewer (Printed Name and Signature) }} \frac{7 / 30 / 26}{\text { Date }}$ 


\author{
WHC-SD-WM-CN-046, Rev.0 \\ HEDOP REVIEN CHECKLIST \\ for \\ Radiological and Nonradiological Release Calculations
}

Document Reviewed: C.H. Huang, "TOXICOLOGICAL DOSE CALCULATIONS FOR SPILL ACCIDENT AT T PLANT," September 24, 1996.

Date Submitted: September 24, 1996.

Scope of Review: Entire Document

YES NO* N/A

D4 [ ] [ ] 1. A detailed technical review and approval of the environmental transport and dose calculation portion of the analysis has been performed and documented.

[X [ ] [ ] 2. Detailed technical review(s) arid approval(s) of scenario and release determinations have been performed and documented.

[ ] [ ] [X 3. HEDOP-approved code(s) were used.

[ $]$ [ ] 4. Receptor locations were selected according to HEDOP recommendations.

[x] [ ] [ ] 5. All applicable environmenta] pathways and code options

[4] [ ] [ ] 6. Hanford site data were used. justified and performed correctly.

[4 [ ] [] 8. The analysis is consistent with HEDOP recommendations.

9. Supporting notes, calculations, comments, comment resolutions, or other information is attached. (Use the "Page 1 of $X$ " page numbering format and sign and date each added page.)

41 [ 10. Approval is granted on behalf of the Hanford Environmental Dose overview Panel.

* Al1. "NO" responses must be explained and use of nonstandard methods justified.

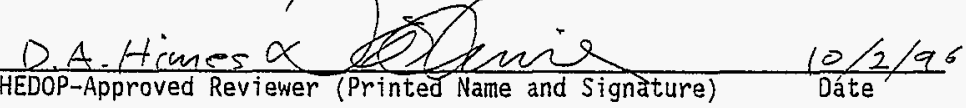

COMMENTS (add additional signed and dated pages if necessary): 


\begin{tabular}{|c|c|c|c|c|c|}
\hline \multicolumn{6}{|c|}{ DISTRIBUTION SHEET } \\
\hline \multirow{2}{*}{$\begin{array}{l}\text { To } \\
\text { B.H. Girbert }\end{array}$} & \multirow{2}{*}{$\begin{array}{l}\text { From } \\
\text { C.H. Huang }\end{array}$} & & & \multicolumn{2}{|l|}{ Page 1 of 1} \\
\hline & & & & \multicolumn{2}{|l|}{ Date $9 / 24 / 96$} \\
\hline \multirow{2}{*}{\multicolumn{4}{|c|}{ Project Title/Work Order }} & \multicolumn{2}{|c|}{ EDT No. 156485} \\
\hline & & & & \multicolumn{2}{|c|}{ ECN No. N/A } \\
\hline Name & MSIN & $\begin{array}{l}\text { Text } \\
\text { With All } \\
\text { Attach. }\end{array}$ & Text Only & $\begin{array}{l}\text { Attach./ } \\
\text { Appendix } \\
\text { Only }\end{array}$ & $\begin{array}{l}\text { EDT/ECN } \\
\text { Only }\end{array}$ \\
\hline $\begin{array}{l}\text { R.F. Carlstrom } \\
\text { T.L. Erickson } \\
\text { J.P. Estrellado } \\
\text { B.H. Gilbert } \\
\text { C.H. Huang } \\
\text { L.E. Johnson } \\
\text { L.S. Semmens } \\
\text { S.M. Stahl } \\
\text { J.C. Van Keuren } \\
\text { Centee Filew }\end{array}$ & $\begin{array}{l}T 4-06 \\
\text { T3-28 } \\
\text { T4-06 } \\
\text { A3-34 } \\
\text { A3-34 } \\
\text { A2-25 } \\
\text { T4-06 } \\
\text { A3-37 } \\
\text { A3-34 } \\
\text { A.3-88 }\end{array}$ & $\begin{array}{l}x \\
x \\
x \\
x \\
x \\
x \\
x \\
x \\
x \\
x\end{array}$ & & & \\
\hline
\end{tabular}

